\title{
The discourse of the US Alt-Right Online - A Case Study of the Traditionalist Worker Party Blog
}

\author{
N Lorenzo-Dus and L Nouri \\ (Swansea University)
}

\begin{abstract}
The use of social media by extreme right groups and the self-proclaimed formation of the 'altright' in recent years have been linked to the rise in US white nationalism. Against a backdrop of widespread concern regarding the growing nature of the 'alt-right' phenomenon, this article responds to the pressing need to understand its appeal. Specifically, we examine the discursive means by which a hitherto unexamined US 'alt-right' group, the Traditionalist Worker Party, constructs its group identity and ideology online. Corpus assisted discourse analysis of this group's blog (c. one million words) reveals that the Traditionalist Worker Party regularly mobilises five discourses (groupness, party politics, race, religion / tradition, change) in order to assert subject positions of victimhood for its (to be) members, alongside recurrent use of explicit out-grouping strategies. The out-groups are blamed for a general malaise - an uncertain, chaotic reality that can and must be changed through affiliation with the Traditionalist Worker Party. The study also shows that the Traditionalist Worker Party constructs itself a highly entitative group as a means to enhancing its recruitment appeal.
\end{abstract}


Keywords: 'alt-right', extreme right, far-right, US White Nationalism, Traditionalist Worker Party, blame, victimhood, corpus assisted discourse studies, online discourse. 


\section{The Discourse of the US Alt-Right Online - A Case Study of the Traditionalist Worker Party Blog}

\section{Introduction}

On Saturday $27^{\text {th }}$ October 2018 Robert Bowers, an individual associated with the 'alt-right', shot and killed eleven people in a Pittsburgh synagogue (The Guardian, 2018). At the time of writing, this attack on the US Jewish community is the latest trend of 'alt-right' violent activity since the 'Unite the Right' rally that took place in Charlottesville, Virginia, on $12^{\text {th }}$ August 2017 (BBC, 2018). Self-identified 'alt-right' leaders and supporters took part in that rally with the overall aim of uniting various extreme conservative factions in the USA. The 'alt-right' is "an amorphous but synchronized collection of far-right people and movements" around the world but centred within the US (Berger, 2018, p. 4). Their specific aim at Charlottesville was to oppose the removal of a statue of Robert E. Lee from Charlottesville's Emancipation Park a statue that for some signifies the oppression of African Americans under slavery and the Jim Crow segregation laws (The New York Times, 2017). In addition to triggering an outbreak of violence that left 19 people injured and one dead, the Charlottesville events made public the formation of the 'alt-right' in the USA, which until then had not been subject to extensive media reporting.

Widespread concern regarding the ever-growing nature of the 'alt-right' phenomenon and its links to a perceived rise in US white nationalism likely account for an increasing number of 
academic studies of the 'alt-right' (see section 2.1). To our knowledge, however, there are no studies of its discourse to date. The main aim of this article is therefore to contribute to fill this important gap in scholarship. Specifically, we adopt a Corpus Assisted Discourse Studies (CADS, henceforth) methodology to analyse the contents of the blog of an influential group in the formation and continuation of the US 'alt-right' - the Traditionalist Worker Party (henceforth, TWP)

\section{Studying the discourse of the 'alt-right'}

\subsection{The online 'alt-right' movement}

Following decades of progressive fragmentation and increasing social stigma of US white nationalism, in 2010 white nationalist ideologue Richard Spencer launched the Alternative Right website, effectively kick-starting the 'alt-right' movement . Spencer is seen as one of, if not the, most public face of the 'alt-right' and as giving the movement its name and cause (Berger, 2018; Southern Poverty Law Center, 2018). Rather than a single or franchise operation, the 'alt-right' consists of a heterogeneous mix of US extreme right ideology groups (Berger, 2018) - a structure that resembles that of the extreme right movement in Europe.

Overall, scholars broadly agree that the 'alt-right' is, at is core, a racist movement encompassing individuals and groups who are intent on the building of a white ethno state. Their chief aim is therefore to secure the dominance of white people and culture across the US and beyond (see e.g. Berger, 2018; Mirrless, 2018). Within this shared aim, 'alt-right' groups actively seek to differentiate themselves from other groups under the 'alt-right' umbrella, such as the so-called 'alt-light' (Florido, 2016). This differentiation concerns the extremity of ideologies and associated violence that each group advocates, ranging from favouring the 
building of territorial ethno States through to calling for the genocide of non-white people (Hawley, 2017; Mirrless, 2018).

For some, the 'alt-right' is one more movement within the ideological umbrella of prowhiteness, which also encompasses white supremacist, neo-Nazi and white nationalist groups. This has led to calls for avoiding the uncritical adoption of the framing of this movement as an 'alternative right' ('alt-right'), which these groups use euphemistically to hide their racist aims (Daniszewski, 2017). For others, what distinguishes the 'alt-right' from other pro-white ideologies is that it has provided "a rhetorical bridge between mainstream public discussion and white nationalism” (Hartzell, 2018, p.8). This rhetorical bridge entails "appeals to intellectualism alongside the trope of 'political correctness"”' that seeks to "move mainstream white folks away from a colorblind racial ideology and toward pro-white racial consciousness” (Hartzell, 2018, p.8). How this rhetorical bridge is discursively built is, however, not specified.

Across its different factions, scholars also agree that the 'alt-right' movement make savvy use of the internet (e.g. Fausset and Feuer, 2017; Goggin, 2017; King, 2017) ${ }^{1}$. Symptomatic of this is the US alt-right groups' active engagement in transgressive trolling and online harassment (Berger, 2018), as well as their spreading of aggressive memes across social media platforms. One example is their capture and repurposing of the Pepe the Frog meme as a means to assert the dominance of White Power online. US alt-right groups are also skilful at taking control over online media narratives surrounding their off-line activities (Goggin, 2017). A case in point is the way in which the success of the 2017 'Unite the Right' rally was falsified by 'alt-

\footnotetext{
${ }^{1}$ Strategy and prolific use of social media affordances by extreme ideology groups (extreme right, white supremacists, jihadist etc.) is well documented (see, e.g.. Boyd, 2008; Copsey, 2003; Fuchs, 2014; KhosraviNik, 2017, 2018).
} 
right groups' leaders - especially the leader of the TWP (see Section 3) through the use of multiple internet platforms.

A further defining feature of the 'alt-right' is their support of US president Donald Trump, which has also helped them politically. While pre-dating Donald Trump's presidential campaign and election in 2016, 'alt-right' groups actively support Trump’s political agenda. US ‘alt-right' leaders such as Matthew Heimbach, Matthew Parrott, Richard Spencer, Andrew Anglin and Nathan Damigo informally campaigned for Trump during his election, viewing him as representative of their cause. Since then, the significance of Trump’s presidency to the rise of US 'alt-right' groups lies in its normalisation of white nationalism, which has brought these groups away from the fringes of politics into mainstream political conversation (Nagle, 2017).

\subsection{The online discourse of US white nationalism}

There is a substantial literature that pre-dates the 'alt-right' movement and examines US white supremacism (see, e.g., Anderson, 2016; Bell, 1963). Within this literature, studies of the discourse of US white supremacist groups are comparatively scarce. Notable exceptions, focusing on online contexts, include analysis of the white supremacist website Stormfront.org (Brindle, 2016a; Baumgarten, 2017) and of the language of Trump’s supporters and their denial of racism on the social media platform Reddit (Subtirelu, 2017).

Brindle's (2016a) analysis focuses on the construction of masculinity within Stormfront website texts centred on the topic of homosexuality. His analysis shows that Stormfront supporters use postings about homosexuality to construct discourses of both heterosexual masculinity and a constellation of intersecting identity features, including gender, race and 
sexuality. The analysis also shows clear othering of Jews, who are constructed as using "ethnic groups, gay men and lesbians and drug users and child sex offenders ... to victimise whites” (2016a, p. 200). Baumgarten’s (2017) analysis of posts to the ‘European Discussion’ forum on Stormfront.org highlights the construction of strong in-group versus out-group adversariality based on three negative properties of the out-group: difference regarding behaviour and personality traits, threats to social structure and social life; and impact on the ingroup's emotional well-being, specifically feelings of insecurity and dissatisfaction. As to who these out-groups are, Baumgarten (2017) argues that the posts discursively construct a wide diversity of 'others' across multiple areas of social life.

As for the language of Trump's supporters online, Subtirelu's (2017) analysis of the discourse of a pro-Trump Reddit community - 'The_Donald' - reveals that its members vehemently deny the presence of racism in Trump's policies and discourse. To do so, they resort to an extended logic of colour-blind racism that polarises online debate by inciting emotional responses from those who do not share their views.

\subsection{The online discourse of extreme right populism}

There is a prolific literature into the (online) discourse of extreme right populist groups in, primarily, Europe (see, e.g. Wodak 2015, Hainsworth 2016; Brindle \& Macmillan 2017; Krzyzanowski \& Ledin 2017; Rydgren 2017). A seminal work within this literature is Wodak’s (2015) comprehensive analysis of the rise of right wing populist discourse in Europe since the 1990s. This analysis clearly pinpoints fear as the chief concept around which extreme right populist discourse centres. Right wing populists groups discursively manipulate public fear of threats to the in-group ('the people'), which they characterise as homogenous and 'pure'. The actual threats are constructed as being plentiful and stemming from diverse sources/out-groups: 
elite groups, changes to 'tradition' (e.g. gender roles), globalisation, immigration and so forth. According to Rydgren (2017), populist ideologies are present in the discourse of extreme right groups in Europe, for whom the elites are responsible for the threats to the in-group (the 'people') posed by immigration, multiculturalism, and the ‘problem' of Islamisation. However, populism is secondary within these groups' ideology, which is dominated by ethnic nationalism.

A number of case studies of extreme right (populist) groups further nuance our understanding of the argumentative and stylistic features that characterise their discourse. For example, using a CADS methodology, Brindle (2016b) finds that group elite and supporters of the extreme right group the English Defence League construct their identity as victims of the UK political establishment, ethnic minorities (Muslims) and police authorities. Brindle and MacMillan’s (2017) CADS of social media content posted by the also UK-based extreme right group Britain First finds evidence of recurring racist and xenophobic stances against Islam and Muslims. And Nouri and Lorenzo-Dus’ (2019) comparative CADS of all the social media (Twitter and Facebook) content posted during a three-month period in 2017 by Britain First and Reclaim Australia identifies more similarities than differences between these two extreme right groups. Chief amongst the similarities is the construction of sui generis imagined political communities that are bound together through exclusion and othering of immigrants and Muslims.

Wodak's (2015) analysis also identifies a common discursive approach by extreme right (populist) groups when it comes to constructing out-group caused threats to the in-group, namely presenting and simultaneously denying use of offensive content (e.g. racism, xenophobia) against the threat carriers (see parallels with Subtirelu's (2017) work above). In doing so, Wodak’s (2015) analysis further shows, these groups' discourse of denial typically 
relies on strategic ambivalence. This enables them both to claim multiple interpretations of their messages (including non-offensive ones) and to blame out-groups for misunderstanding their messages, which they then use to lend further weight to their victimised group claims.

\subsection{The appeal of extreme ideology discourse}

In his influential study of ideology and discourse, van Dijk (1998) defines ideology as the "axiomatic" basis of the mental representations that members of a social group share. These representations provide "the basic principles that govern social judgement", that is to say, they determine what group members believe to be (in)correct and (un)true. The main function of ideologies is the "co-ordination of the social practices of group members for the effective realisation of the goals of a social group, and the protection of its interests” (1998, p. 24). They are thus instrumental to social groups' identity construction. Although there is not a predetermined set of discursive social group ideologies, van Dijk (1998) reminds us, many rely on 'us versus them' argumentative strategies. The result is opposition-based boundary setting, which can be openly polarised in the case of extreme ideology groups, including elites (e.g. certain media outlets and political parties).

Identity polarisation is a defining property of social groups that display high entitativity entitativity being a scalar property that accounts for what makes a group "groupy” (Campbell, 1958; Hamilton and Sherman, 1996). High entitativity groups demarcate boundaries very clearly, maximising perceived differences between them and out-groups. High-entitativity groups also stress the importance of internal homogeneity, social interaction amongst their members, and of members' holding common goals and fates (Hamilton, Shearman \& Rodgers, 2004). Based on these properties there is no doubt that the groups reviewed in Sections 2.1 2.3, which regularly resort to identity polarisation and othering, display high entitativity. 
The above is important when it comes to trying to explain the success of extreme right ideology groups, including those within the 'alt-right' movement on which this study centres. According to the tenets of 'uncertainty-identity' theory (Hogg, 2004, 2014), high entitativity works as an effective group recruitment tool, especially in times of (perceived) uncertainty. This is because feelings of uncertainty - including those generated through threat-induced fear - motivate behaviours aimed at reducing them. Central amongst these behaviours is being able to characterise self and others as belonging to a certain group. A group provides a consensually validated social identity, which not only describes but also prescribes who one is and how one should behave. High entitativity groups do this most effectively. Tested via human participant experimental techniques, uncertainty-identity theory has successfully explained the rise of zealotry and the lure of extremist ideologies in times of societal unrest and change, such as the rise of religious fundamentalism during the early Renaissance (Hogg, Adelman and Blagg, 2010). It has also explained the current rise of both anarchism-related political and neo-fascist groups (Gaffney, Rast, Hackett and Hogg, 2014).

\section{The Traditionalist Worker Party}

The TWP emerged in 2015 as the political branch of the Traditionalist Youth Network (TYN). It claims to be the "first political party created by and for working families" in the USA (TWP, N.D). Indicative of US alt-right groups' tendency to self-define in comparison / contrast to other groups within the US alt-right movement, the TWP assert that they should not be seen as affiliated with US racist groups. The TWP demarcate themselves as a politically motivated group. Their overriding goal, however, is better epitomised by the following statement, found on their now defunct website: 
While we have candidates for political office and will run campaigns, that work is secondary to our first priority, which is local organizing and advocacy for reallife working families who share our identitarian and traditionalist vision (TWP, N.D).

The TWP is co-led by Matthew Heimbach and his father-in-law, Matthew Parrott. Heimbach has founded and consecutively led several other US 'alt-right' groups: the Youth for Western Civilization society at Towson University in Maryland, the White Students' Union also at Towson University in Maryland and the TYN (Anti-Defamation League, 2018). He is also one of the three leaders of the racist umbrella group Nationalist Front and a member of the neoconfederate League of the South. Unsurprisingly, then, Heimbach is regarded as a rising star in the white supremacist world (Anti-Defamation League, 2018). Heimbach first attracted significant media attention for his involvement in the Charlottesville rally. . The pre-during and post- rally online documentation that he (and other 'alt-right' groups' leaders) posted resulted in it being heralded as the event that brought the US 'alt-right' together (Glowicki, 2017).

Like other 'alt-right' groups, the TWP makes use of multiple online environments, ranging from traditional (website, blog) through to social media platforms. The group ran an active blog between $1^{\text {st }}$ April 2009 and March 2018. During this time, it also had a website, which was taken down by Matthew Parrott in March 2018, following the arrest and charge of Matthew Heimbach for assaulting his wife (Southern Poverty Law Center, 2018). As for the TWP's social media presence, this includes a YouTube account, a Facebook page, an official Twitter account and a number of individual accounts by its leaders (e.g. @TradYouth and @TWP). These accounts, however, appear to be under-used. For example, although the total number of 
tweets written by and to (@) the TWP official Twitter account between $11^{\text {th }}$ April - $11^{\text {th }}$ August 2017 amounted to 1.2 million (> 23 million words), less than twenty tweets were posted by the TWP account. Furthermore, this Twitter corpus contained a high number of hyperlinks to the TWP blog. As such, their blog was considered the best data source for our study, as we next describe.

\section{Methodology}

\subsection{Data}

The data for this study comprise all the entries posted on the TWP blog from $1^{\text {st }}$ April 2009 until $30^{\text {th }}$ November 2017. This amounts to 1,333,814 words, spread across 905 blog entries. The number of blog entries posted per year in our corpus is distributed as follows: 38 in 2009; 31 in 2010; 49 in 2011; 14 in 2012; 163 in 2013; 178 in 2014; 234 in 2015; 136 in 2016, 62 in 2017. All the entries were authored by Matthew Heimbach and / or Matthew Parrot. The only image in the blog was Heimbach's profile picture. No details about how or why the blog was created were mentioned in the blog, the contents of which were published through the Creative Commons (httpps://creativecommons.org/) copy-left license.

\subsection{Framework and Procedure}

Our study uses a CADS methodology, which has proved particularly useful when seeking to understand the recurrent ways in which groups discursively construct their / others' identities across digital media (see, e.g., Zappavigna, 2012; Hardaker and McGlashan, 2016). This not only owes to CADS' use of software and statistics, which facilitates linguistic interrogation of large digital datasets, but also to CADS' premise that quantitative (corpus) and qualitative (discourse) analyses of language provide a “useful methodological synergy” (Baker et al., 2008 - see also, e.g., Hardt-Mautner, 1995; Partington, 2004). This integration of corpus and 
discourse analyses “can bring together social relevance and statistical relevance” (Marchi and Taylor, 2018, p.4). On the one hand, corpus analysis can "provid[e] more neutral starting points and generalisability, i.e., accounting for the scale of phenomena”. On the other, "the overall 'qualitative' nature of the [discourse] analysis guards against the commonly lamented trouble within quantitative studies, that is, their disregard for context” (Marchi and Taylor, 2018, p. 4).

Procedurally, CADS typically follows a “serendipitous” journey of discovery (Partington, 2006, p. 12), whereby corpus linguistics-software enabled searches of datasets are treated as “an initial 'map’ [...] pinpointing areas of interest for a subsequent close analysis” (Baker et al., 2008, p. 284). In the present study, the following analytic steps were followed:

a) Downloading all the TWP blog entries, saving each of them as a separate .txt file and running them through a Part of Speech (PoS) and lemma tagger. Further pre-processing of the dataset for Corpus Linguistics software analysis ${ }^{2}$ entailed removing illegal UTF8 characters.

b) Calculating distributional lexical information in the corpus, specifically word frequency lists and lexical dispersion values. Word frequency lists rank words on the basis of the number of times that they appear in a corpus. Lexical dispersion indicates how evenly spread a word is across a corpus; its calculation is standard in corpus analyses that, like ours, do not involve comparison between datasets (see Gries, 2008; Brezina, McEnery and Wattam, 2015). The lexical dispersion measure we applied was

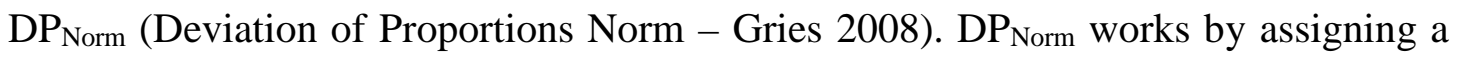
value that ranges from zero (0) to one (1) - the closer to a zero 0 value a word has, the

\footnotetext{
${ }^{2}$ We used CQPWeb (http://cwb.sourceforge.net/cqpweb.php) for the analysis, with the exception of the calculation of lexical dispersion values, which was processed through \#LancsBox

(http://corpora.lancs.ac.uk/lancsbox/; Brezina, McEnery and Wattan, 2015).
} 
more dispersed it is across a corpus; the closer to a 1 value a word has, the less dispersed it is. In order to calculate $\mathrm{DP}_{\text {Norm }}$ values through \#LancsBox, the TWP blog corpus was converted into plain .txt files - each blog entry being saved to a single plain-text file. After observing that words with a dispersion value $>0.53$ tended to appear in a small number of the TWP blog entries, we decided to conduct further analyses based on that 'cut-off' point. This yielded a list of 145 words, from which we manually excluded all the function words. From the resulting 57 words, 22 were further excluded because of their low number of occurrences in the corpus, which was insufficient to calculate their statistically significant collocates [see step c)]. We henceforth refer to the resulting set $(n=35)$ of frequent and highly dispersed content words in the corpus as salient words within the TWP blog.

c) Calculating the statistically significant collocates for our salient words. We used Log Ratio as our measure for collocational strength. Log Ratio is an effect-size metric that describes how big /important a given difference is. In our case, it determined how big the difference between the use of a collocate with a given salient word was when compared with the use of that word with all its other possible collocates in the corpus.d) Manually examining all the extended concordance lines, i.e., full sentences and paragraphs, for all the collocations derived from step c). This led to our inductively deriving a number of recurring thematic categories - or discourses - within the TWP blog. Use of this manual, inductive process yields fine-grained, context/topic sensitive coding than that resulting from the automated (software-derived) classification of semantic domains (for a discussion, see Jaworska and Kinloch, 2018). The examples (i.e., extended concordance lines) included in this article are typical realisations of the discourse to which their respective collocations was assigned as a result of this final step in the study's analytic procedure. 


\section{5.}

\section{Results and Discussion}

Five discourses emerged from the analytic steps outlined in section 4.2, namely: groupness, party politics, race, religion/tradition, and change. These appear in the left-hand column of Table 1. In the right-hand column, a list is provided of the salient words (underlined) contributing to each discourse, alongside their statistically significant collocates. Some salient words appear listed against more than one discourse. This is because their meaning in context varied depending on their collocates. For example, the salient word 'man' contributed to constructing the groupness discourse when used alongside the collocates common and fellow. It contributed to constructing the race discourse when it collocated with white, and the religion/tradition discourse when it collocated with woman.

[Table 1 near here]

\subsection{Groupness}

The groupness discourse was characterised by clear boundary demarcation between homogenous, victimised in-groups and multiple, blameworthy out-groups. A number of collocations stressed commonality of features within given in-groups, as Example 1 and 2 illustrate:

1. Corneliu Codreanu [...] said "When we speak of the Romanian nation, we refer not only to the Romanians currently living on the same territory, with the same past and same future, the same habits, the same language, the same interests.” 
2. To be a part of [the US] nation is to be a part of an extended family, bound together by blood and soil; no piece of paper or government pronouncement can make you a part of a nation,... only blood can.

The TWP blog characterised in-groups' members as being bound by strong national ties that operated across multiple homogeneity vectors. In Examples 1 and 2, these concerned geography ('the same territory' - 1, 'bound together by ...soil' - 2), tradition ('the same habits' - 1), goals ('the same interests' -1) and genealogy/race ('bound together by blood' - 2). Having 'the same language’ (1) also featured regularly in the discourse of groupness. Creating a connection between in-group identity and language as a means to construct a homogenous national identity is typical of extreme right populist discourse in Europe, too. The "national language” is depicted in such cases as being both pure and the language of the "real” citizens of that nation (Wodak, 2015).

In the case of the US nation, and as Example 2 illustrates, in-group members were assigned the subject position of being 'a part of an extended family'. The metaphor of the US nation as a family likely struck a chord with US readers of the blog, as it has been often used, and continues to do so, by mainstream (both Republican and Democrat) leaders in US politics(Lakoff, 2002).

In addition to being represented as homogeneous, in-groups were constructed as suffering at the hands of out-groups and, therefore, as victims. Consider Examples 3 and 4:

3. Yet while innocent white people are losing their lives, suffering from horrific cancers and diseases caused by corrupt politicians and crony corporations...

4. ... the Greek people's struggles as the forces of globalism continue to wage an economic, social, and spiritual war against the Greek nation and the Greek Church. 
In-groups were constructed as 'suffering from'(3), 'losing their lives' (3), and 'struggl[ing]' (4). Their victim status was highlighted through explicit identification of the out-groups who were responsible for their predicament. A "blame maker” (the victimised in-group) versus "blame taker" (the threatening out-group) frame was thus constructed (Angouri \& Wodak, 2014). In Examples 3 and 4, these blame takers were elite groups: 'Corrupt politicians and crony corporations' (3) and 'the forces of globalism' (4). This populist rhetoric was reinforced across other discourses in the corpus, such as overt opposition to intellectualism - dressed as 'political correctness' (see Section 5.2).

Within the US national context, and realised via collocations containing the salient words 'America' and 'American', blame takers were typically ideologies of exceptionalism, multiculturalism and the so-called American dream (see Examples 5-6):

5...our bastardization of the Gospel into being about wealth and American exceptionalism has rotted her to the core.

6...the radical notion of selfish individualism which has come to dominate both our politics and culture, and dispense with the " becoming as wealthy as possible and then investing that wealth in aggrandizing yourself.

Blame-takers were not only explicitly identified in the TWP blog but also had their wrongdoings described in detail. In examples 5-6 they were held responsible for the 'bastardization' of faith ('the Gospel') and the 'rott[ing]' of 'her' [America] (5). The origin of these wrongdoings was seen to lie in extremism itself, which was bred within the USA (note the use of first person plural deixis in 5 ('our bastardization') and 6 ('our politics and culture’)). This disdain on America - and specifically the perceived turn towards the political left therein - was a 
regular feature the discourse of groupness in the corpus and has been associated with the 'altright' movement (Hartzell, 2018).

Overall, the TWP discourse of groupness clearly demarcated in- and out-groups such that the in-groups were constructed as being both homogeneous and victims of threatening out-groups, who were responsible for the in-groups' predicament and, hence, blameworthy. As the remainder of this article shows, this demarcation permeated across all the other discourses in the TWP blog, thus confirming both the group's high entitativity and fear of threats-driven victimhood as its chief identity feature.

\subsection{Party Politics}

A wide range of socio-political issues was regularly discussed within the party politics discourse (see Table 1). This is not to say that its readers were presented with a distinctive and comprehensive set of policies covering the issues being raised. Instead, analysis of the concordances comprising the party politics discourse collocations showed at best superficial engagement with a broad, unstructured set of issues, ranging from employment (e.g. wages, work) and communication (e.g., political correctness) through to justice (e.g., high-level conceptualisation of rights). References to political correctness were always derogatory (e.g. 'the wolves of political correctness'), which supports characterisation of the 'alt-right' as a populist, anti-political correctness movement (Hartzell, 2018). For their part, different types of rights were categorically asserted as 'fundamental' to in-groups, including rights to selfdetermination for 'Afrikaner people', to worship for Christians and to 'preserve their own Heritage \& Culture’ for ‘every people on Earth ... even if that means creating a separate nation for themselves'. 
Significantly, in-group victimisation ran across the many issues covered within the party politics discourse in the TWP blog. We next use one salient word ('power') and its statistically significant collocates (see Table 2) to illustrate this recurrent pattern in the corpus.

[Table 2 near here]

The analysis of the concordances for the collocations in Table 2 and 3 revealed that 'power' was imbued with a highly negative discourse prosody. Regardless of the specific issues being discussed, victim (blame maker) - perpetrator (blame taker) subject-positions were regularly constructed, of which Example 7is typical:

7. ... the exploitation that is currently holding the Appalachian people in bondage to ruthless capitalists and the globalist power structure.

In Example 7, a 'globalist power structure' was linked to 'ruthless capitalists' and blamed for 'the exploitation that is currently holding the Appalachian people' - that is, for the in-group's (here, the Appalachian people) victim status. Through the political party ideological discourse, the TWP weblog constructed the in-group's reality as being in turmoil as a result of groups that effected 'positions' of 'power' and 'influence' (Table 2). The negative prosody of 'power' in particular resonates with the discourse of populism (Rydgren, 2017). The in-group was constructed as having endured this chaos for a long time, stretching to the present (see Section 5.5 - Change).

All in all, through its party politics discourse, the TWP blog did not put forward concrete political party policies. Instead, it vividly and recurrently painted an uncertain picture of reality for the in-group, for which out-groups took the blame. Antagonism towards others (e.g. groups in power) is a central, recurring concept in the identity politics of extreme right populist groups, 
which in turn creates a "politics of exclusion” (Wodak, 2015). Clear-cut blaming of out-groups within the TWP's politics of exclusion further enhanced its entitativity.

\subsection{Race}

Unsurprisingly, given the US 'alt-right' links to white nationalism, the TWP blog regularly engaged in the discursive construction of race-related beliefs. This was done in two, partially overlapping ways. One of them involved explicit discussion of the in-group’s racial identity; the other entailed discussion of the in-group’s native status in US territory.

Let us firstly consider salient words and collocations linked to the explicit discussion of racial identity (Table 3).

[Table 3 near here]

When used alongside the collocates 'man' and 'men', white constructed a discourse of racial victimhood, as illustrated in Examples 8 and 9:

8. The blood of every white man who is lost in the Empire's wars for the globalists.

9. . Amid the desert of meaning into which Millennials were born, the new far right expertly pinpointed the existential questions, particularly for those who couldn’t be permitted a collective identity, namely straight white men: who are we?

In both examples, the white man/men was presented as being under threat, be that physical (blood shed - 8) or existential (collective identity denial - 9). In Example 9, a particular refinement was provided as regards the in-group's identity, which concerned sexuality, for it was not simply 'white men' but 'straight white men' who were portrayed as having their rights 
curtailed ('[not] permitted a collective identity’). This was frequent in the TWP blog, which often described its prototypical members as: heterosexual + white + male (see Section 5.4). This clustering coincides with a number of the socio-demographics ascribed to the US 'altright', whose members reject mainstream conservatism and neoliberalism and who seek to dismantle the perceived Republic and Democratic establishment in the US (Flisfeder, 2018).

Across these prototypical identity traits, in-group's victimhood once again ran strongly in the corpus, as evidenced by the collocates of the salient word 'white': guilt, genocide and advocates (see Examples 10-11). The two other salient collocates of 'white' in Table 3 (saviorism, saviors) served to differentiate the in-group (whites) from other groups that were also seen to operate within a race-relations framework.

10. In case you're still keeping score, the author is proposing "extreme violence” against Whites who attempt to establish safe spaces for themselves to peacefully survive in away from the totalitarian Leftist state which cannot suffer their very existence. This is White Genocide, plain and direct.

11. We are nationalists, not hate filled supremacists (unlike the political mainstream in the Zionist State), but the media continues to promote the lie of White advocacy as being "racist".

The above examples illustrate the construction of in-/ out- groups in typical ideological square (Van Dijk, 1998) style. The actions and properties of the in-group ( 'whites' - 10; 'nationalists'11) were positively portrayed (e.g. 'attempt to establish safe spaces for themselves to peacefully survive' - 10). In sharp contrast, the actions and properties of the out-groups ('the System' - 10; 'the totalitarian Leftist state' - 10; the 'media' and 'the political mainstream in the Zionist State' - 11) were negatively represented: 'proposing “extreme violence” against 
Whites ... 'White Genocide' - 10. No negative in-group representations were provided; nor were any positive out-group representations conceded.

As for the discourse of race in terms of the in-group's claim to US land native status, this was constructed via the salient collocations 'America + founding, whites, multicultural', of which Examples 12-13 are typical.

12. His [Mr. Tyler’s] campaign slogan, "Make America White Again," confirms that he’s fully committed to making a stand against the demographic challenge to America's founding identity.

13...an increasingly multicultural America with a decaying infrastructure, a lack of industrial production , rising national debt, low wages and national disunity will...

In Example 12, the adjective 'demographic' was used to modify the evaluative noun 'challenge', which was in turn post-modified via the nominal phrase 'America's founding identity'. The latter is an example of a packaged-up information clausewhich is particularly effective in political discourse to mask ideology through presupposition. In Example 12, then, the author presupposed that their target readership knew - and agreed - that (i) America had a foundational identity that was racially white and that (ii) demographics posed a challenge to that identity. The actual nature of that demographic challenge was not verbally explicated. However, by repurposing as ‘Make America White Again’ the original slogan by Trump (and formerly by President Reagan) 'Make America Great Again', the challenge could be easily retrieved as being non-white demographics. In Example 13, 'multicultural America' was described through a highly negative lexical chain from semantic domains that are unrelated to race and multiculturalism, belonging instead to the macro-realms of economy and politics: 
'decaying infrastructure, a lack of industrial production, rising national debt, low wages and national disunity'. Both examples, which are typical of the construction of "subtle racism" by political elites (see, e.g. van Dijk, 1993), may be indicative of attempts by the TWP to position itself at the moderate end pole of the US 'alt-right' extremism and violence continuum (see Section 2.1).

\subsection{Religion / Tradition}

Religion, and more specifically Christianity, was another recurrent discourse in the TWP blog. The predominance of Christianity is a feature of 'alt-right' discourse that seems to differentiate it from extreme right populist discourse in Europe, where religion also features but to a lesser extent. Analysis of the extended concordance lines pertaining to this discourse revealed two complementary constructions of the notion of Christianity: as the gateway to the in-group and as justification for the TWP's take on tradition.

Firstly, Christianity was positively appraised as giving access to all that was good about the ingroup. Thus, it was said to be the right 'way' to find one's place in an idealised in-group. This 'way', was laid out in the New Testament and the book 'The Way of the Pilgrim' (see Example 14), was evaluated as the only way (15) and as having 'a profound impact' on 'every aspect of my life' (14 - note the TWP's leader adoption of animator, author and principal speaker roles (Goffman, 1981), hence signalling ‘authenticity’ through personal commitment).

14. ...the wisdom found in The Way of the Pilgrim ... have had a profound impact not just on my spiritual life, but on every aspect of my life.

15. The only way to save Christianity in the West ... is to fight this battle within our respective churches with everything we have. 
Secondly, the Christian way of life was discursively constructed as being firmly anchored in tradition and, in turn, a legitimate reason for immutability regarding a number of gender/sexuality issues. Collocates of the salient word 'years', such as thousand (see Example 16), were typical of this ideological construction:

16. Bishop Kallistos Ware said on this subject "The ordination of women to the priesthood lacks all basis in Scripture and Tradition, and after two thousand years we have no right to innovate in a matter of such importance. ”

In this example, the passing of time ('after two thousand years') and direct quotation from ecclesiastical authority ('Bishop Kallistos Ware', himself referencing 'Scripture and Tradition') were used to legitimate maintaining the status quo as regards the non-ordinance of women to priesthood. Note the use of nominalisation (use of the noun 'ordinance' rather than of a conjugated form of the verb to ordain) and ellipsis (avoidance of the requisite negative particle to describe a situation in which ecclesiastic authority are not ordaining women). Also noteworthy was the use of typographical convention (specifically, capitalisation) to assign proper noun (and hence unique) status to the common nouns (i.e., generic objects) 'Scripture' and 'Tradition'.

A recurring feature of the religion / tradition discourse is that the in-group (here, Christians) were portrayed as being under significant threat. The positive, traditional Christian way of life was represented as having been endangered throughout history ('The first thousand years of Christian Sacred Tradition were tossed out the window when...'). Christians' victimhood indeed persecution - was regularly referenced across the blog entries, including through the collocations ' $\underline{\text { down }}+$ tearing (17) / break' (18).

17. ... democracy has begun tearing down the Church brick by brick. 
18. ... the mass media and government run schools to break down the ancestral identity and culture of the European Christian people.

The blame-takers for Christians’ victimhood were also explicitly identified ('democracy’ - 17; 'the mass media and government' - 18), their negative actions / properties being boosted through evaluative lexis ('tearing down' - 17; 'break down' - 18) and stylistic resources such as repetition ('brick by brick’ - 17).

\subsection{Change}

The last discourse in the TWP blog was that of change, specifically the need to effect it. Change was presented as an imperative given the TWP's constructions of victimhood across its other discourses. Faced with the chaotic, uncertain world generated by out-groups, the TWP blog stated, the in-group must make its in-group loyalty explicit. Examples 19 and 20 illustrate this discourse of change in relation to the salient word 'new' and some of its statistically significant collocates:

19. As the homo futura, you don't have to sit back and attempt to win over the homo inferior. Your goal should be to literally create a new nation and leave the old species behind.

20. Creation of songs, propaganda, stories, articles, and other media sources can encourage the faithful, educate new recruits, and expand our message to an ever growing number of the public.

Both examples are typical of the TWP using its weblog to mobilise its readers into strategic action. In Examples 19 and 20 this was respectively expressed via obligation and possibility modality verbs. In Example 19, the modal verbs '(not) have to' and 'should' unambiguously 
specified the direction of travel, the 'goal', for the TWP weblog target readership, who was addressed directly ('you’) and through the generic - and stylistically keyed as playful - label of 'the homo futura'. This goal, which was to be taken 'literally,' entailed that this 'homo futura' 'should create a new nation'. It was a goal that also required both 'leav[ing] the old species behind' and, implicitly, the old ways in which change may have been attempted, namely 'sit[ing]back and attempt[ing] to win over the homo inferior'. In Example 20, a selection of specific actions was offered ('Creation of songs, propaganda, stories, articles, and other media sources') as possibilities ('can') for achieving an equally specific selection of aims within a broad recruitment agenda: 'encourage the faithful, educate new recruits, and expand our message to an ever growing number of the public.'

As noted in Section 2, there were numerous hyperlinks to the TWP blog from social media (Twitter) accounts to / by the TWP. The authors of the TWP blog were able to use the interconnectedness of the digital space to advance their goals, in the case of the discourse of change in Examples 19 and 20 through calls to action. The presence of this discourse of change in the TWP blog was also important in terms of providing the kind of concrete actions that high entitative groups favour - a clearly laid out instructional path to follow. The path was evaluated positively (e.g. as that chosen by an evolved human species - 20) and safely nested in reassuring we-ness ('our message', 20). The discourse of change across the TWP blog thus reflected and further constructed the TWP as highly entitative by showing that, in addition to being historically and presently bounded together through victimhood across a range of issues, it also shared a vision for shaping its fate.

\section{Conclusion}

This article provides the first discourse analysis of US 'alt-right', including novel academic examination of an influential group therein - the TWP. Our analysis has shown that the TWP 
blog constructs five recurring discourses: groupness, party politics, race, religion / tradition and change. In terms of groupness, the TWP clearly demarcates in-groups from out-groups, respectively assigning subject positions of victimhood and threat to them. This is characteristic of a commonly used blame-maker versus blame-taker frame in (right wing) populist discourse. In the case of the TWP blog, the frame permeates across all five discourses, effectively becoming its overarching discourse. Moreover, the TWP groupness discourse places great emphasis upon the homogeneity of in-groups’ members, which it constructs around notions of shared goals, language, territory and tradition. This contributes to the group’s high entitativity, As for the party politics discourse, this touches upon diverse socio-political issues, including political correctness and human rights. The TWP blog is highly critical of political correctness. This has been also noted in the discourse of far / extreme right groups, where political correctness is constructed as a limit to the in-groups' freedom of expression and thus used to support their victimhood status. By strongly asserting the various rights of the in-group, the TWP draws attention away from the actual policies that may enable delivery of those very rights. Their party politics discourse is therefore broad, assertive and, largely, content-free. This finding resonates with the online use of a diluted political ideology discourse by extreme right wing groups elsewhere as a means to increase their supporter base (Brindle \& Macmillan, 2017; Nouri \& Lorenzo-Dus, 2019).

The discourses of race and religion/ tradition are, when compared to that of party politics, more focused. They align the TWP firmly within a white nationalist/ supremacist agenda: the superiority of Christianity, the importance and immutability of 'traditional' values (including around gender/sexuality) and the stronghold of a native in-group over US geographical territory. Some of these values - specifically white nationalism and anti-immigration - feature in the findings of the 2018 Alt-Right Twitter census, which also identifies as prevalent: pro- 
Trump, general far-right and conspiracy/fake news content, and deliberately transgressive, offensive or provocative material, often humorously presented (Berger, 2018).

Overtly aggressive language, for instance taboo words and denigration through offensive labelling of out-groups, is not a salient feature in the TWP blog. Instead, more 'subtle' forms of, for example, racial discrimination are used. Witty/humorous keying of messages is observed in our corpus, for instance in relation to the discourse of change. Frequently, too, a confidence heuristics style is deployed, consisting of unmitigated assertions worded as 'statements of fact' rather than as opinions. Confidence heuristics is known to be one of the discursive markers of influence in online settings (Lorenzo-Dus \& Di Cristofaro, 2016). We cannot determine, with the methodology used in this study, how successful this style was in terms of TWP recruitment of supporters. However, the style is typical of high entitativity groups as it relies on clear-cut demarcation of in/out groups.

The analysis has shown that the discourse of TWP overwhelmingly constructs subject positions of victimhood for its (to be) members, alongside explicit and also recurring out-grouping strategies. The out-groups are blamed for a general malaise - a chaotic reality that must be changed. Expectedly, change is possible through affiliation to the TWP.

Use of this 'out-group provoked crisis - in-group enabled solution' discourse strategy is common across other extremist ideology formations, ranging from jihadi ideology groups (see e.g. Lorenzo-Dus \& Macdonald, 2018) and US white supremacists (Brindle, 2016a/b) through to populist (de Vreese et al, 2018) and extreme right groups (e.g. Wodak, 2015; Brindle \& Macmillan, 2017). Granted, there are nuances to the crises caused by/ threats posed by different out-groups, as well as to the solutions that are presented as being within the exclusive gift of the in-groups. Identifying what these crises and solutions are can help delineate the, admittedly, fuzzy contours of the manifold manifestations of political extremism. Specifically, and as per 
our case study's main aim, it can also help unveil what the discourse of particular groups within the US 'alt-right' movement stand for.

Our analysis shows that the TWP, despite its self-proclamation as part of the recently established 'alt-right' and as disassociated with racist groups, are actually a new iteration of a long-established trend of US white nationalism. Indeed, what they are manifesting online is similar to that of what has been seen of European extreme right groups online. What is also illuminative about this study into their online discourse is how they are feeding off uncertainties felt by some in the US today. The five discourses identified offer us an insight into the appeal of these groups and thus gives policy makers an opportunity to reduce the adverse effect of these groups and potentially reduce their entitativity.

\section{Acknowledgements}

The authors are very grateful for feedback received on previous versions of this article presented at The Orfalea Center for Global and International Studies, University of California Santa Barbara in April 2018 and the Edith Cowan Centre for Global Issues, Edith Cowan University, Australia, in November 2018. Additionally, the authors would like to thank Dr Matteo Di Cristofaro for his assistance processing and analysing the corpus data.

\section{References}

Anderson, C (2016) White Rage: The Unspoken Truth of Our Racial Divide. US: Bloomsbury Publishing.

Angouri , J and Wodak, R (2014) 'They became big in the shadow of the crisis': The Greek success story and the rise if the far right. Discourse \& Society 25 (4): 540-565. 
Anti-Defamation League (ADL) (2018) Former Youth for Western Civilization Leader Promotes White Student Union at Towson. Available at: https://www.adl.org/blog/formeryouth-for-western-civilization-leader-promotes-white-student-union-at-towson (accessed 13 May 2019).

Baker P, Gabrielatos C, KhosraviNik M, et al. (2008) A useful methodological synergy? Combining critical discourse analysis and corpus linguistics to examine discourses of refugees and asylum seekers in the UK press. Discourse \& Society 19(3): 273-306.

BBC (2018) Charlottesville remembered: 'A battle for the soul of America'. Available at: https://www.bbc.co.uk/news/world-us-canada-

44619374?intlink_from_url=https://www.bbc.co.uk/news/topics/cremmjz8rx4t/charlottesvill e\&link_location=live-reporting-story (accessed 13 December 2018).

Baumgarten, N (2017) Othering practice in a right-wing extremist online forum. Language @ Internet 14 Available at: https://www.languageatinternet.org/articles/2017/baumgarten (accessed 22 August 2019).

Bell, D (1963) The dispossessed. In: Bell D (ed) The radical right: The new American right. New York: Doubleday.

Berger, JM (2018) The Alt-Right Twitter Census: Defining and Describing the Audience for Alt-Right Content on Twitter. VOX-POL. Available at: https://www.voxpol.eu/download/voxpol_publication/AltRightTwitterCensus.pdf (accessed 13 December 2018).

Boyd, D (2008) Can social network sites enable political action? In A. Fine, M.Sifry, A. Rasiej, and J. Levy (eds) Rebooting America ., Mountain View: Creative Commons, 112-116. 
Brezina, V. McEnery, T. and Wattan, S. (2015) Collocations in context: A new perspective on collocation networks. International Journal of Corpus Linguistics, 14(1): 29-59.

Brindle, A. (2016a) Cancer has nothing on Islam: A study of discourses by group elite and supporters of the English Defence league. Critical Discourse Studies 13 (4): 444-459.

Brindle, A. (2016b) The language of hate: A corpus linguistics analysis of white supremacist language. London: Routledge.

Brindle A and MacMillan C (2017) Like and share if you agree: A study of discourses and cyber activism of the rar right British nationalist party Britain First. Journal of Language Aggression and Conflict 5(1): 108-133.

Campbell, DT (1958) Common fate, similarity, and other indices of the status of aggregates of persons and social entities. Behavioural Science 3: 14-25.

Copsey, N (2003) Extremism on the net: The extreme right and the value of the internet. In R. Gibson, P. Nixon, and S. Ward (eds) Political parties and the internet: Net gain?,, London: Routledge, 218-233..

Daniszewski, J (2017) How to describe extremists who rallied in Charlottesville. Associated Press Available at: https://blog.ap.org/behind-the-news/how-to-describe-extremists-whorallied-in-charlottesville (accessed 01 May, 2019).

Fausset, R and Feuer, A (2017) Far-eight groups surge into national view in Charlottesville. The New York Times. Available at: https://www.nytimes.com/2017/08/13/us/far-right-groupsblaze-into-national-view-in-charlottesville.html (accessed 17 December 2018). 
Flisfeder, M (2018) “Trump”-What does the name signify? or, protofascism and the alt-right: Three contradictions of the present conjuncture. Cultural Politics 14(1): 1-19.

Florido, A (2016) The White Nationalist origins of the term "alt-right" - and the debate around it. Available at: www.npr.org/ 2016/11/27/503520811/the-white-nationalist-origins-of-theterm-alt- right-and-the-debate-around-it?t=1534781671383 (accessed 13 December 2018)

Gabrielatos, C and Baker, P (2008) Fleeing, sneaking, flooding: A corpus analysis of discursive constructions of refugees and asylum seekers in the UK press, 1996-2005. Journal of English Linguistics 36 (1): 5-38.

Fuchs, C (2014) Social media: A critical introduction. London: Sage.

Gaffney, A M, Rast, D E III, Hackett, JD and Hogg, MA (2014) Further to the right: Uncertainty, political polarization and the American "Tea Party" movement. Social Influence 9: $272-288$.

Glowicki, M (2017) President Trump appeals to Higher Court to dismiss Louisville Rally suit $\begin{array}{llll}\text { Courier } & \text { Journal. } & \text { Available } & \text { https://eu.courier- }\end{array}$ journal.com/story/news/crime/2017/07/24/trump-appeals-higher-court-dismiss-louisvillerally-suit/505044001/ (Accessed 17 May 2019).

Goffman, E. (1981) Forms of Talk. Oxford: Blackwell.

Goggin, B (2017) Meet the Neo-Nazi at the heart of the Charlottesville rally. Digg. Available at: http://digg.com/2017/matthew-heimbach-alt-right-charlottesville-unite-the-right (accessed 17 May 2019). 
Gries, S T (2008) Dispersions and adjusted frequencies in corpora. International Journal of Corpus Linguistics, 13(4), 403-437.

Hainsworth, P. (2016) Politics of the Extreme Right: From the margins to the mainstream. New York: Bloomsbury.

Hamilton, DL \& Sherman, SJ (1996). Perceiving persons and groups. Psychological Review, 103: 336-355.

Hamilton, DL, Sherman, JS and Rodgers, JS (2004) Perceiving the groupness of groups: Entitativity, homogeneity, essentialism and stereotypes. In V. Yzerbyt, CM Judd, O Corneille (eds.) The psychology of group perception: Perceived variability, entitativity, and essentialism, New York: Psychology Press, 39-60.

Hardaker, C. and McGashan, M. (2016), 'Real men don’t hate women’: Twitter rape threats and group identity. Journal of Pragmatics 91: 80-93.

Hard-Mautner, G. (1995) 'Only connect': Critical discourse analysis and corpus linguistics. UCREL Technical Paper 6. Lancaster: University of Lancaster.

Hartzell, S (2018) Alt-White: Conceptualizing the “Alt-Right” as a rhetorical bridge between white nationalism and mainstream public discourse. Journal of Contemporary Rhetoric 8(1/2): 6-25.

Hawley, G (2017) Making sense of the Alt-Right. New York: Columbia University Press. 
Hogg, M (2004) The social identity perspective: Intergroup relations, self-conception, and small groups. Small Group Research 35(3): 246-276.

Hogg, M (2014) From uncertainty to extremism: social categorization and identity processes. Current Directions in Psychological Science 23(5) 338-342.

Hogg M, Adelman, JR and Blagg, RD (2010) Religion in the face of uncertainty: An uncertainty-identity theory account of religiousness. Personality and Social Psychology Review 14: 72-83.

Jaworska, S and Kinloch, K (2018) ‘Using multiple data sets’. In Taylor C and Marchi A (2018) (eds) Corpus Approaches to Discourse. London: Routledge, 110-129.

KhosraviNik, M. (2017) Right wing populism in the west: Social media discourse and echo chambers. Insight Turkey 19 (3): 53-68.

KhosraviNik, M( 2018) Social media techno-discursive design, affective communication and contemporary politics. Fudan Journal of the Humanities and Social Sciences 11(4): 427-442.

King, $\mathrm{R}$ (2017) This Indiana man is in the middle of the 'Unite the Right' rally in Charlottesville. Indy Star. Available at: https:/eu.indystar.com/story/news/2017/08/12/uniteright-white-nationalist-rally-charlottesville-erupts-violence/562095001// $\quad$ (accessed 17 December 2018).

Krzyzanowski, M \& Ledin, P (2017) Populism in/and the borderline discourses of exclusion Journal of Language and Politics 16(4): 566-581.

Lakoff, G (2002, $2^{\text {nd }}$ edn.) Moral politics: What Conservatives know the Liberals don't. Chicago: Chicago University Press. 
Lorenzo-Dus, N and di Cristofaro, MD (2016) \#Living/minimum wage: Influential citizen talk in twitter. Discourse, Context \& Media 13: 40-50.

Lorenzo-Dus, N and Macdonald, S (2018) Othering the West in the online jihadist propaganda magazines Inspire and Dabiq. Journal of Language Aggression and Conflict 6(1):79-106.

Mirrlees, T (2018) The Alt-Right’s discourse of “Cultural Marxism”: A political instrument of intersectional hate. Atlantis 39(1): 49-69.

Nagle, A (2017) Kill all normies: Online culture wars from 4Chan and Tumblr to Trump and the Alt-Right. Washington, DC: Zero Books.

Nouri, L., \& Lorenzo-Dus, N (2019). Investigating Reclaim Australia and Britain First’s use of social media: Developing a new model of imagined political communities online. Journal for Deradicalization 18: 1-34.

Partington, A (2004) Corpora and discourse, a most congruous beast. In A. Partington, J. Morley \& L. Haarman (eds.) Corpora and Discourse. Bern: Peter Lang, 11-20.

Partington A (2006) The Linguistics of laughter A Corpus-assisted study of laughter-talk. London: Routledge.

Rydgren, J. (2017) Radical right-wing parties in Europe. What's populism got to do with it? Journal of Language and Politics 16 (4): 485-496.

Southern Poverty Law Center (SPLC) (2018) Alt-Right. Available at: www.splcenter.org/fighting-hate/extremist-files/ideology/alt-right (accessed 17 May 2019).

Subtirelu, N (2017) Donald Trump supporters and the denial of racism. Journal of Language Aggression and Conflict 5 (2): 323-346. 
Taylor, C and Marchi, A (2018) (eds) Corpus Approaches to Discourse. London: Routledge

The Guardian (2018) Pittsburgh synagogue shooting: suspect Robert Bowers charged with 11 counts of murder. Available at: https://www.theguardian.com/us-news/2018/oct/27/pittsburghsynagogue-shooting (accessed 17 May 2019).

The New York Times (2017) The Statue at the Center of Charlottesville’s Storm. Available at: https://www.nytimes.com/2017/08/13/us/charlottesville-rally-protest-statue.html (accessed 17 May 2019)

Van Dijk, TA (1993) Elite discourse and racism. London: SAGE Publications.

Van Dijk, TA (1998) Ideology: A multidisciplinary approach. London: SAGE Publications.

Wodak, R (2015) The politics of fear: What right-wing populist discourses mean. London: SAGE Publications.

Zappavigna, M. (2018) Discourse of Twitter and social media. London: Continuum. 
Table 1

Table 1: Discourses in the TWP Blog

\begin{tabular}{|c|c|}
\hline Discourse & Salient word (statistically significant collocates) ${ }^{3}$ \\
\hline Groupness & 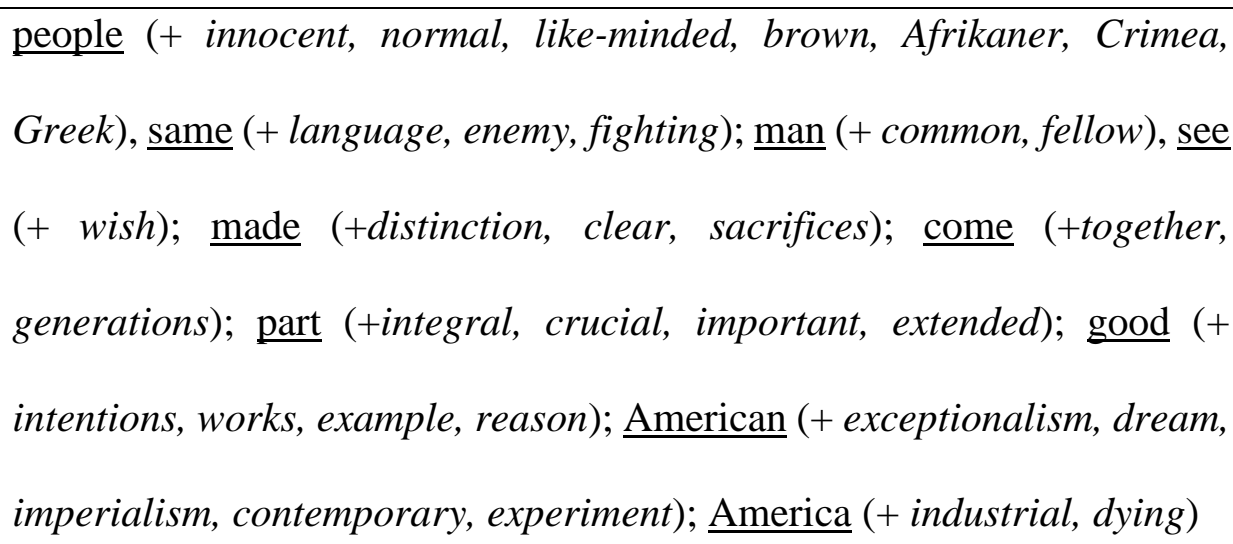 \\
\hline Party politics & $\begin{array}{l}\text { political (+ correctness, process, machine, mainstream, grassroots); right } \\
(+ \text { dissident, fundamental, exist); work }(+ \text { dismantle); social } \\
\text { (+engineering, construct, contract, experiment, status, pressure, } \\
\text { advocates, justice); power (+ structure, influence, positions, money, } \\
\text { Jewish); world (+ third, immigrants, subversion, domination, war II); } \\
\text { down (+ throats, wages); }\end{array}$ \\
\hline Race & $\begin{array}{l}\text { white (+ Saviorism, saviors, guilt, genocide, advocates); } \text { America (+ } \\
\text { founding, whites, multicultural); } \text { man }(+ \text { white }) \text {; men }(+ \text { white })\end{array}$ \\
\hline Religion / & $\begin{array}{l}\text { new }(+ \text { Testament), way }(+ \text { Pilgrim, find, best, only), down }(+ \text { handed, } \\
\text { tearing, break); life }(+ \text { limb, sanctity, Legionnaire, eternal), years }(+ \\
\text { thousand), } \underline{\operatorname{man}}(+ \text { woman }), \underline{\text { men }(+ \text { women })}\end{array}$ \\
\hline
\end{tabular}

\footnotetext{
${ }^{3}$ Collocates appear next to its respective salient word, inside brackets, in italics and in decreasing Log Ratio value order.
} 


\begin{tabular}{|l|l|}
\hline Change & $\begin{array}{l}\text { men }(+ \text { young }) ; \underline{\text { time }}(+ \text { wasting, waste, spend, energy), new }(+ \text { recruits, } \\
\text { create, requirements); world }(+ \text { modern, material }) ; \underline{\text { became }}(+ \text { closer } \\
\text { revolutionary, part })\end{array}$ \\
\hline
\end{tabular}

Table 2: Collocates of 'power' 4

\begin{tabular}{|c|c|c|c|}
\hline Collocate & $\begin{array}{c}\text { Total no. in } \\
\text { whole corpus }\end{array}$ & $\begin{array}{r}\text { In no. of } \\
\text { texts }\end{array}$ & Log Ratio \\
\hline structure & 55 & 18 & 7.137 \\
\hline influence & 181 & 10 & 3.963 \\
\hline positions & 114 & 6 & 3.889 \\
\hline money & 504 & 19 & 3.605 \\
\hline Jewish & 1274 & 35 & 3.445 \\
\hline
\end{tabular}

Table 3 - Selection of key collocates of the salient words' 'man' / 'men' and 'white' 5

\begin{tabular}{|l|r|r|r|}
\hline Collocate & $\begin{array}{r}\text { Total no. in } \\
\text { whole corpus }\end{array}$ & In no. of \\
texts & Log Ratio \\
\hline \multicolumn{2}{|c|}{ 'man' } \\
\hline
\end{tabular}

\footnotetext{
${ }^{4}$ The information in this and subsequent tables providing details of collocational structures is to be interpreted as follows. The salient word being examined appears between inverted commas (in Table 2, 'power'). Statistically significant collocates linked to a given discourse (in Table 2, party politics) appear, in decreasing order of collocational strength, listed under the column 'collocate'. The next two columns present further details of the respective collocation. In Table 2, for instance, 'structure' was the top collocate of 'power', with a Log Ratio value of 7.137. This collocation appeared 55 times, across 18 different weblog entries.

${ }^{5}$ As regards 'man' / 'men', Table 3 contains only collocations contributing to the discourse of race, namely: white, in both cases. The other key collocations of 'man' and 'men' were tied to other discourses - see Table 1.
} 


\begin{tabular}{|c|c|c|c|}
\hline white & 3121 & 47 & 1.856 \\
\hline \multicolumn{3}{|c|}{ 'men' } \\
\hline white & 3121 & 69 & 2.683 \\
\hline \multicolumn{3}{|c|}{ 'white' } \\
\hline saviorism & 9 & 7 & 10.355 \\
\hline saviors & 19 & 37 & 10.066 \\
\hline advocates & 118 & 17 & 5.798 \\
\hline guilt & 72 & 36 & 4.993 \\
\hline genocide & 132 & & \\
\hline
\end{tabular}

